\title{
The Isoenzymes of Lactate Dehydrogenase in the Nephron') of the Healthy Human Kidney
}

\author{
By K. G. Thiele 2 ) and H. MatTenheimer \\ From the Renal and Nutrition Section, Division of Medicine, and Department of Biochemistry, Presbyterian-St. Luke's Hospital, \\ and Department of Biochemistry, University of Illinois, College of Medicine, Chicago, Illinois, U.S.A.
}

(Eingegangen am 3. Februar 1968)

Herrn Prof. Dr. Dr. Karl Lobmann in Verebrung zum 70. Geburtstag gewidmet

\begin{abstract}
Die Isoenzymmuster der LDH wurden in mikrosezierten anatomischen und funktionellen Einheiten des Nephrons der gesunden Menschenniere bestimmt. In den Glomeruli war die Aktivität von LDH-2 und LDH-5 niedrig, während die anderen Fraktionen wesentlich stärker und ungefähr gleich aktiv waren. In den gewwndenen Harnkanälchen und in den Medullarstrahlen war LDH-1 die aktivste Fraktion, gefolgt von LDH-2, während nur wenig LDH-3 und fast keine Aktivität von LDH-4 und LDH-5 gefunden wurde. Zur Papille hin nahm die Aktivität von LDH-1 und LDH-2 ab, während LDH-3 und LDH-4 stärker hervortraten. Auch LDH-5 nahm zu, jedoch war der höchste Einzelwert in der äußersten Spitze der Papille nur 19\% der Gesamt-LDH-Aktivität.

In der Menschenniere besteht kein direkter Zusammenhang zwischen Stoffwechseltyp, respiratorisch oder glykolytisch, und den LDHIsoenzymmustern.

Der insgesamt niedrige Prozentsatz der LDH-5 in der Menschenniere ist bemerkenswert, und es ist schwer verständlich, daß andere Autoren bei bestimmten Nierenerkrankungen einen Anstieg der LDH-5, deren Ursprung sie in der Niere glauben, im Serum fanden.

Isoenzyme patterns of LDH have been determined in micro dissected anatomical and functional units of the nephron of the healthy human kidney. In glomeruli the activities of LDH-2 and LDH-5 were low, while the other fractions were considerably more and about equally active. In convoluted tubules and medullary rays LDH-1 was the most active fraction, followed by LDH-2. There was little activity of LDH-3 and almost no activity of LDH-4 and LDH-5. Towards the papilla the activity of LDH-1 and LDH-2 decreased, while LDH-3 and LDH-4 became increasingly prominent. LDH-5 also increased, but the highest single value in the very tip of the papilla was only $19 \%$ of the total $\mathrm{LDH}$ activity.

There ist no strict relation between the LDH-isoenzyme patterns and the type of metabolism, respiratory or glycolytic, in the human kidney.

The overall low percentage of LDH-5 in the human kidney is remarkable, and makes it difficult to understand the results of other authors who found that in certain kidney diseases the activity of LDH-5, which they believe to originate from the kidney, is increased in serum.
\end{abstract}

The presence of four or five isoenzymes of $\mathrm{LDH}^{3}$ ) in the human kidney has been demonstrated by several authors. While LDH-1 and/or LDH-2 were found to be predominant in most investigations (1-8) WIEME and MAERCKE (9) reported the lowest activities in these fractions and about equal activities in LDH-3, LDH-4, and LDH-5. The very complex anatomical structure of

1) Supported by Grant HE 03912, HE 05529 and 5-K3-GM-15, 524, United States Public Health Service and Contract DA-49-193MD-2625, United States Army Medical Research and Development Command.

2) Research Fellow (1965) at Presbyterian-St. Luke's Hospital, on leave of absence from I. Medizinische Klinik im Allgemeinen Krankenhaus Hamburg-Barmbeck, Germany.

3) Definitions and Abbreviations.

Nomenclature of the kidney:

Cortex: Glomeruli, proximal and distal convoluted tubules, medullary rays.

$O M Z=$ outer zone of the medulla: straight parts of proximal and distal tubules, loops of HENLE and collecting ducts.

$\mathrm{IMZ}=$ Inner zone of the medulla: loops of HENLE and collecting ducts.

Papilla: mainly collecting ducts, some loops of HENLE.

Enzyme units:

$\mathrm{U}=\mu \mathrm{Moles}$ substrate metabolized $/ \mathrm{min}$. at $25^{\circ} \mathrm{C}$ (or $37^{\circ} \mathrm{C}$ where stated).

$\mathrm{mU}=0.001 \mathrm{U}$.

LDH-isoenzymes: $\mathrm{LDH}-1$ = heart type, LDH-5 = muscle type.

$\mathrm{LDH}=$ Lactate Dehydrogenase (L-Lactate: NAD oxidoreductase, EC 1.1.1.27). the kidney and differences in blood flow, oxygen supply and oxygen consumption in the various areas lead one to expect differences in the isoenzyme patterns in the structurally and functionally different parts of the nephron.

WiELAND et al. (1) and Richterichi et al. (5) found no differences in the LDH-isoenzyme patterns between cortex and medulla of the human kidney, but a separation in just these two areas is very coarse and does not take into account structural differences within the cortex and within the medulla. The cortex contains glomeruli, proximal and distal convoluted tubules and medullary rays. The "medulla" can be divided in three areas: the outer zone (OMZ) with the straight parts of the tubuli, loops of HENLE and collecting ducts, the inner zone (IMZ) with loops of HENLE and collecting ducts, and papilla with collecting ducts.

The technique developed in our laboratory (10) to dissect from frozen dried kidney sections various anatomical and functional units of the nephron which has been applied to study the quantitative distribution of enzymes in the nephron with ultramicro chemical methods (10-13), proved to be applicable to determine the LDHisoenzyme patterns in the various parts of the nephron (14).

The studies to be described deal with the LDH-isoenzyme patterns of the healthy human kidney. 


\section{Methods}

\section{Tissue preparation}

Kidney tissue was obtained at autopsy (not later than 6 hours after death) and by surgical biopsy and divided under a stereomicroscope $(20 \times$ magnification) in cortex, medulla and papilla. Homogenates $(5-10 \% \mathrm{~W} / \mathrm{V})$ were prepared in triethanolamine buffer pH 7.5, 0.05 $\mathrm{M}$ in a Potrer Elvehjem all glass homogenizer, and centrifuged at $20000 \mathrm{~g}$ at $4^{\circ} \mathrm{C}$. The supernatants were used for isoenzyme electrophoresis.

To prepare frozen dried sections the tissue was frozen in liquid nitrogen immediately after it was obtained. Serial sections, $16 \mu$ thick, were cut in a cryostat at $-20^{\circ} \mathrm{C}$. After freeze drying the sections were stored at $-35^{\circ} \mathrm{C}$. For details of tissue preparation and microdissection of various cell groups of the nephron see references $(10,11)$.

For the electrophoretic demonstration and the assay of the isoenzymes the weight of the dissected specimens had to be between approximately 1 and $5 \mu \mathrm{g}$. Each specimen was transfered into $1 \mu \mathrm{l}$ of barbital buffer and the insoluble material was removed after stirring for approximately $1 \mathrm{~min}$. with a pointed glass needle. The droplet was transfered with a glass capillary on to the cellulose acetate gel strips.

\section{Electrophoresis}

The method of KENNY and RAFELSON $(15,16)$ was used. Electrophoresis buffer: $7.84 \mathrm{~g}$ anhydrous sodium acetate, $20.00 \mathrm{~g}$ sodium diethylbarbiturate, $6.84 \mathrm{~m} / 2 \mathrm{~N} \mathrm{HCl}$ in 4 liters of distilled water. $\mathrm{pH}=8.6$.

Staining solution: to $0.45 \mathrm{~m} / 60 \%$ D-L-sodium lactate add $3 \mathrm{ml}$ electrophoresis buffer. Dissolve $14 \mathrm{mg}$ NAD in $2 \mathrm{ml}$ electrophoresis buffer and add to the above solution. Dissolve $16 \mathrm{mg}$ nitroblue tetrazolium (NBT) in $2 \mathrm{~m} /$ electrophoresis buffer and add to the above solution. Just prior to use dissolve $1.2 \mathrm{mg}$ phenazine methosulfate (PMS) in $1 \mathrm{ml}$ electrophoresis buffer and add to the above solution.

Fixing solution: $5 \mathrm{ml}$ glacial acetic acid, $5 \mathrm{ml} 95 \%$ ethanol and $90 \mathrm{ml}$ distilled water.

Clearing solution: $500 \mathrm{~m} / 5 \%$ acetic acid, $450 \mathrm{ml} 95 \%$ ethanol, $50 \mathrm{ml}$ 4-hydroxy-4-methyl-2-pentanone.

Electrophoresis was carried out on cellulose acetate gel strips (Cellogel, Colab Laboratories, Chicago Heights, Illinois) at $4^{\circ} \mathrm{C}$, $150 \mathrm{~V}, 0.5-0.75 \mathrm{~mA} / 2.5 \mathrm{~cm}$ of strip for $90 \mathrm{~min}$. For enzyme staining strips of cellulose acetate paper ( $\mathrm{S}$ and $\mathrm{S}, \mathrm{Colab}$ ) was soaked with staining solution and placed on a glass plate. The cellogel electrophoresis strips were laid on the incubation strips and incubated in a moist airtight plastic container at $37^{\circ} \mathrm{C}$ in the dark for 30-60 min. (Sandwich technique). After staining the electrophoresis strips were transfered into fixing solution, after 3-5 min. washed with distilled water, and then immersed in clearing solution for $10 \mathrm{~min}$. The strips were then placed on a clean glass plate, opaque side down, making certain no ait bubbles are trapped underneath the strip. The glass plate was then incubated in an oven at $75^{\circ} \mathrm{C}$ for $5-10$ min., until the strips became transparent. After cooling to room temperature the strips were peeled from the glass plate and stored in cellophane envelopes. For scanning the Joyce Chromoscan was used.

\section{Quantitative determination of $L D H$ activity}

Dissected cell groups were weighed on a quarz fiber balance and LDH activity assayed with a fluorimetric method $(10,11,17)$. Activity measurements in tissue extracts were done with a microliter spectrophotometric method (17).

\section{Results}

\section{Evaluation of the technique}

The technique employed to demonstrate the isoenzymes of the LDH gave a very satisfactory resolution of the fractions (fig. 1), but inherent in enzyme staining pro-

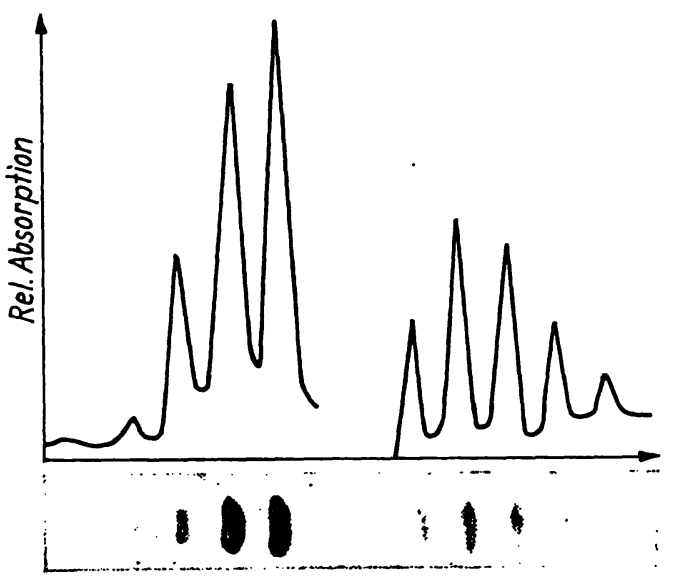

Fig. 1

LDH-electropherograms of the human kidney Left: Right: papilla

The anode is to the right and LDH-1 is closest to the anode

cedures is the danger of overstaining or understaining, which leads to a non proportional pattern. Overstaining occurs when in a mixture of fractions with high and low relative enzymatic activity the activity of the former decreases as the maximum color development is reached, while the latter are still maximally active, thus leading to an overestimation of the activity of the less active fractions. Understaining on the other hand can leave a fraction of low activity undetected. The total activity applied and the incubation time have therefore to be carefully balanced. The optimum assay conditions were checked and the reproducibility of the results evaluated by analyzing simultaneously various amounts of an extract of rat kidney cortex with $\mathrm{LDH}$ activities from 2.25 to $18 \mathrm{mU}$ under identical conditions (tab. 1). A change of the $\mathrm{LDH}$-isoenzyme patterns in favor of the slower moving fractions was observed with increasing total LDH

Tab. 1

Reproducibility of LDH-isoenzyme patterns. Comparison of various activities of extracts from homogenates of rat kidney cortex. All electropherograms were treated identically

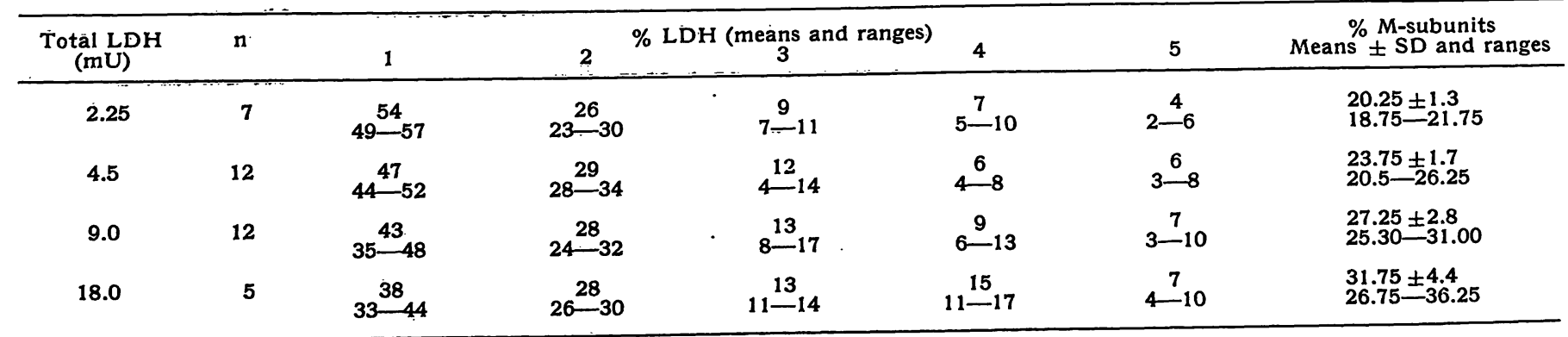


activity. The means of the percent $\mathrm{M}$-(muscle)-subunits (see discussion on page 136) increase with the total LDH activity. This is to be expected in these patterns with prevalence of LDH-1 and LDH-2 and is most likely due to overstaining of the less active fractions.

It is obvious from inspection of the data that both the means and the variances are directly associated with the level of total LDH activity. The observed differences do not outweigh the differences between the LDH-isoenzyme patterns in the various structures of the nephron, if the total LDH activity is kept within a practical range of about 1-5 $\mathrm{mU}$. Very good reproducibility with least variation was found with 2.25 and $4.5 \mathrm{mU} \mathrm{LDH}$. With higher concentrations the variation increased somewhat. Repeated scanning of a single electropherogram gave identical results.

The activity applied with the dissected specimens or extracts from the human kidneys ranged from approximately 1 to $5 \mathrm{mU}$. The activity of LDH in the various parts of the nephron $(11,12,33)$ is shown in table 2.

Tab. 2

Activity ( $\mu$ Moles/g dry tissue $\times$ min. at $37^{\circ} \mathrm{C}$ ) of lactate dehydro-

\begin{tabular}{|c|c|c|c|c|}
\hline & $\begin{array}{c}\text { Adults: mean values } \\
\text { [] number of patients } \\
\text { () range }\end{array}$ & $\begin{array}{l}\text { Lived } \\
10 \mathrm{~min} .\end{array}$ & $\begin{array}{l}\text { Infants } \\
1 \text { year } \\
\text { old }\end{array}$ & $\begin{array}{l}5 \text { year } \\
\text { old }\end{array}$ \\
\hline Glomeruli & $\begin{array}{c}635 \\
(453-1069)\end{array}$ & 1357 & 645 & 618 \\
\hline $\begin{array}{c}\text { Prox. conv. } \\
\text { tubules }\end{array}$ & $\left.{ }_{(1058-2217}^{1417}\right)^{[10]}$ & 2092 & 1280 & 2045 \\
\hline $\begin{array}{l}\text { Dist. conv. } \\
\text { tubules }\end{array}$ & $(980-1583){ }^{[10]}$ & 2916 & 530 & 1359 \\
\hline $\begin{array}{l}\text { Medullary } \\
\text { rays }\end{array}$ & $(980-1972)^{[6]}$ & 2057 & 915 & 2130 \\
\hline $\mathrm{OMZ}$ & $(825-1715)^{[5]}$ & 1309 & 817 & 1340 \\
\hline IMZ & ${ }_{(580-2120)^{[5]}}^{1135}$ & - & 1045 & 1517 \\
\hline Papilla & $(583-1289)^{[3]}$ & - & 847 & - \\
\hline
\end{tabular}

It had been previously reported from this laboratory that no differences in total LDH activity could be detected between autopsy and biopsy material, and that on storage of frozen dried sections over several years at $-35^{\circ} \mathrm{C}$ no changes in total activity occured (11). Some of the investigations on $\mathrm{LDH}$-isoenzymes were done on frozen dried kidney sections which had been stored for up to 5 years. The results were within the range observed with recently prepared sections. Alterations of the LDHisoenzyme patterns by freeze drying kidney sections were excluded (14).

\section{Kidney homogenates (tab. 3)}

In homogenates of the cortex of the human kidney LDH-1 and LDH-2 were predominant and on the average equally strong. LDH-5 was detectable only with $1-5 \%$ of the total LDH activity. Homogenates of medulla (OMZ + IMZ) showed a slight decrease of LDH-1 and LDH-2 and some increase in LDH-4, while LDH- 5 was unchanged.

The peak of the activity in homogenates from papilla was in LDH-3. As compared to cortex and medulla
Tab. 3

LDH-isoenzymes in extracts from homogenates from the various zones of the human kidney. $A=$ kidneys obtained at autopsy. $B=$ tissues obtained by surgical biopsy

\begin{tabular}{|c|c|c|c|c|c|c|}
\hline & $(+) 1^{\text {Per }}$ & ${ }_{2}^{\text {cent dist }}$ & $\begin{array}{c}\text { ibution } \\
3\end{array}$ & $\underset{4}{f}$ isoenzyr & ${ }_{5}$ & $\begin{array}{l}\text { Percent } M- \\
\text { subunits }\end{array}$ \\
\hline \multicolumn{7}{|c|}{ Cortex } \\
\hline $\begin{array}{l}A-1 \\
A-2 \\
A-3 \\
B-1 \\
B-2 \\
\text { Mean } \\
\text { Range }\end{array}$ & $\begin{array}{c}34 \\
49 \\
29 \\
38 \\
38 \\
38 \\
29-49\end{array}$ & $\begin{array}{c}42 \\
27 \\
30 \\
32 \\
32 \\
32 \\
27-42\end{array}$ & $\begin{array}{c}20 \\
17 \\
24 \\
22 \\
23 \\
21 \\
17-24\end{array}$ & $\begin{array}{c}3 \\
6 \\
12 \\
7 \\
6 \\
7 \\
3-12\end{array}$ & $\begin{array}{r}1 \\
1 \\
5 \\
1 \\
1 \\
2 \\
1-5\end{array}$ & $\begin{array}{c}23.75 \\
20.75 \\
33.50 \\
25.25 \\
20.00 \\
25.75 \\
20.0-33.5\end{array}$ \\
\hline \multicolumn{7}{|c|}{ Medulla (OMZ + IMZ) } \\
\hline $\begin{array}{l}A-1 \\
A-2 \\
A-3 \\
B-1 \\
B-2 \\
\text { Mean } \\
\text { Range }\end{array}$ & $\begin{array}{c}25 \\
35 \\
31 \\
35 \\
34 \\
32 \\
25-35\end{array}$ & $\begin{array}{c}27 \\
25 \\
27 \\
29 \\
27 \\
27 \\
25-29\end{array}$ & $\begin{array}{c}28 \\
25 \\
22 \\
21 \\
24 \\
24 \\
21-28\end{array}$ & $\begin{array}{c}16 \\
13 \\
16 \\
12 \\
12 \\
14 \\
12-16\end{array}$ & $\begin{array}{r}4 \\
2 \\
4 \\
3 \\
3 \\
.3 \\
2-4\end{array}$ & $\begin{array}{c}36.75 \\
30.50 \\
33.75 \\
29.75 \\
30.75 \\
32.25 \\
29.75-36.75\end{array}$ \\
\hline \multicolumn{7}{|c|}{ Papilla } \\
\hline $\begin{array}{l}\mathrm{A}-1 \\
\mathrm{~A}-2 \\
\mathrm{~A}-3 \\
\mathrm{~B}-1 \\
\mathrm{~B}-2 \\
\text { Mean } \\
\text { Range }\end{array}$ & $\begin{array}{c}16 \\
17 \\
11 \\
17 \\
21 \\
17 \\
11-21\end{array}$ & $\begin{array}{c}22 \\
27 \\
25 \\
25 \\
22 \\
24 \\
22-27\end{array}$ & $\begin{array}{r}39 \\
45 \\
34 \\
28 \\
24 \\
32 \\
24^{-45}\end{array}$ & $\begin{array}{c}22 \\
11 \\
23 \\
20 \\
21 \\
20 \\
11-23\end{array}$ & $\begin{array}{c}1 \\
<1 \\
7 \\
10 \\
12 \\
7 \\
1-12\end{array}$ & $\begin{array}{c}42.50 \\
37.50 \\
47.50 \\
45.25 \\
45.25 \\
44.00 \\
37.5-45.25\end{array}$ \\
\hline
\end{tabular}

LDH-1 had decreased most and LDH-2 slightly. There was some further increase in LDH-4 and LDH-5. The highest activity of LDH- 5 was $12 \%$ of the total $\mathrm{LDH}$ activity. There was no difference between kidney tissue obtained at autopsy or by surgical biopsy.

\section{Dissected tissue specimen (tab. 4 and 5)}

The LDH-isoenzyme pattern of human glomeruli was characterized by almost equal activities of LDH-1, LDH-3 and LDH-4, while the activities of LDH-2 and LDH-5 were low.

In dissected convoluted tubules LDH-1 was the strongest fraction with $57 \%$ on the average and a range from $34-75 \%$, the activity of the other fractions decreased from LDH-2 to LDH-5, the latter was demonstrable only occasionally.

The LDH-isoenzyme pattern in medullary rays was little different from the pattern of convoluted tubules.

In the OMZ LDH-1 was on the average less strong than in convoluted tubules and medullary rays, and LDH-3 had increased. Little change was found in the other fractions.

The isoenzyme patterns exhibited marked differences between OMZ, IMZ and papilla. LDH-1, still predominant in the OMZ, decreased on the average to $15 \%$ of the total activity in the IMZ and to $8 \%$ in the papilla. A slighter decrease was observed for $\mathrm{LDH}-2$. Concomitantly the activities of LDH-3 and LDH-4 increased, LDH-3 becoming the most active fraction in the IMZ and the papilla. The activity of LDH-5 increased on the average from $1 \%$ in the convoluted tubules and medullary rays to $2 \%$ in the OMZ, $7 \%$ in the IMZ and $11 \%$ in the papilla. Further differences were observed within the papilla in tissue dissected from the base, the center and the tip (tab. 5). The data were obtained from one kidney only. From base to tip LDH-1 decreased while LDH-5 increased. 
Tab. 4

LDH-isoenzymes in dissected groups of cells from the various functional and anatomical units of the human nephron [] number of kidneys () number of analyses

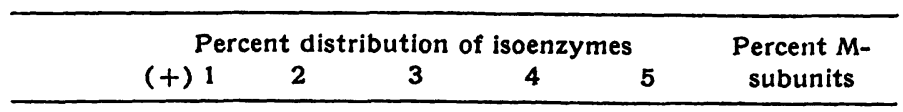

Glomeruli

[2] (3)

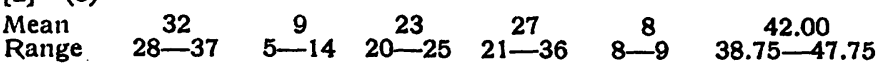

Conv. tubules

[5] (30)

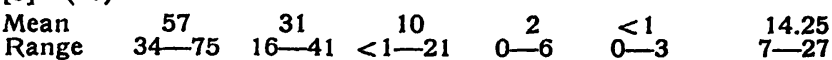

Medullary rays

[4] (9)

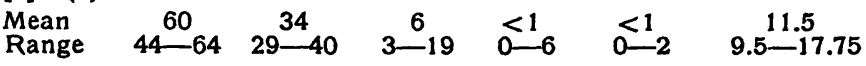

OMZ

[5] (7)

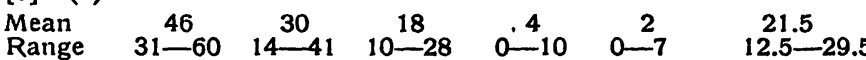

I $M Z$

[4] (6)

$\begin{aligned} & \text { Mean } \\ & \text { Range }\end{aligned} \quad 8 \stackrel{15}{-23} \quad 14^{23}-31 \quad 27 \stackrel{34}{-41} \quad 17 \stackrel{21}{-26} \quad 5 \stackrel{7}{-12} \quad 39.25-50.5$

Papilla

$\begin{array}{lllllll}\text { Mean } & 8 & 817 & 35 & 29 & 11 & 54.50 \\ \text { Range } & 2-17 & 8-30 & 27-43 & 14^{-38} & 6-19 & 45-62.5\end{array}$

Tab. 5

LDH-isoenzymes in dissected tissue from various areas of the papilla of the human kidney

\begin{tabular}{lcccccc}
\hline & \multicolumn{9}{c}{ Percent distribution of isoenzymes } & \multicolumn{2}{c}{$\%$ M- } \\
& $(+) 1$ & 2 & 3 & 4 & 5 & subunits \\
\hline $\begin{array}{l}\text { Base }(n=3) \\
\text { Mean }\end{array}$ & & & & & \\
Range & $10-17$ & $14-17$ & $27-38$ & $24-35$ & $6-9$ & 51 \\
$\begin{array}{l}\text { Center }(n=1) \\
\text { Mean }\end{array}$ & 10 & 17 & 33 & 27 & 13 & 54 \\
$\begin{array}{l}\text { Tip }(n=3) \\
\text { Mean } \\
\text { Range }\end{array}$ & $2-9$ & $13-16$ & $30-35$ & $31-36$ & $12-19$ & 59 \\
\hline
\end{tabular}

The mean values and ranges in convoluted tubules which constitute about $60 \%$ of the kidney cortex, differed somewhat from the means and ranges in cortex homogenates. In convoluted tubules LDH-1 on the average was more pronounced than in cortical homogenates. This difference can not be accounted for by the fact that cortex homogenate contains in addition to convoluted tubules, medullary rays and glomeruli, because in both structures LDH-2 was less active than in LDH-1.

To explore the discrepancy between dissected convoluted tubules and total cortex homogenate, repeated analyses of dissected convoluted tubules were done. In a single kidney values between $\mathrm{LDH}_{-1} 1=74 \%, \mathrm{LDH}-2=16 \%$, LDH $-3=6 \%$ and $\mathrm{LDH}-1=42 \%$, LDH- $2=40 \%$, $\mathrm{LDH}-3=14 \%$ were found in one and the same experiment, with cell groups dissected from various areas, ruling out variation introduced by the technique of isoenzyme assay, and strongly indicating that the isoenzyme pattern varies within the cortex. But no significant differences could be detected between cortex corticis and center and inner cortex.
The same type of variation was observed within medullary rays, independent whether medullary rays were dissected from more outer or more inner parts of the cortex.

\section{Dissected specimens from kidneys from infants (tab. 6)}

LDH-isoenzyme patterns in dissected tissue specimens from infants' kidneys, ranging from a stillbirth up to five years of age, were within the range obtained for adult kidneys.

Tab. 6

LDH-isoenzymes in dissected groups of cells from infants' kidneys. (1) stillbirth (2) death $10 \mathrm{~min}$. after birth (3) one year old (4) 5 year

\begin{tabular}{|c|c|c|c|c|c|c|}
\hline & & It di & ution & soen & & Percent $M$ - \\
\hline & $(+) 1$ & 2 & 3 & 4 & 5 & subunits \\
\hline Glom $\underset{(2)}{\operatorname{m}} \operatorname{eruli}$ & 47 & 16 & 21 & 16 & $<1$ & 26.50 \\
\hline Convoluted & $d t u b$ & & & & & \\
\hline $\begin{array}{l}(1) \\
(2) \\
(3) \\
(4)\end{array}$ & $\begin{array}{l}50 \\
68 \\
45 \\
57\end{array}$ & $\begin{array}{l}28 \\
19 \\
27 \\
34\end{array}$ & $\begin{array}{r}18 \\
5 \\
18 \\
9\end{array}$ & $\begin{array}{l}4 \\
6 \\
6 \\
0\end{array}$ & $\begin{array}{r}<1 \\
3 \\
4 \\
0\end{array}$ & $\begin{array}{l}19.00 \\
14.75 \\
24.25 \\
13.00\end{array}$ \\
\hline Medullary & rays & & & & & \\
\hline $\begin{array}{l}\text { (1) } \\
(2) \\
(3) \\
(4)\end{array}$ & $\begin{array}{l}47 \\
32 \\
44 \\
72\end{array}$ & $\begin{array}{l}25 \\
26 \\
29 \\
28\end{array}$ & $\begin{array}{r}22 \\
30 \\
19 \\
0\end{array}$ & $\begin{array}{r}10 \\
10 \\
6 \\
0\end{array}$ & $\begin{array}{l}2 \\
3 \\
2 \\
0\end{array}$ & $\begin{array}{r}26.75 \\
32.00 \\
23.25 \\
7.00\end{array}$ \\
\hline Medulla (OI & $M Z+$ & & & & & \\
\hline $\begin{array}{l}\text { (1) } \\
(2) \\
(3) \\
(4)\end{array}$ & $\begin{array}{l}26 \\
32 \\
39 \\
51\end{array}$ & $\begin{array}{l}32 \\
26 \\
29 \\
32\end{array}$ & $\begin{array}{l}32 \\
30 \\
20 \\
14\end{array}$ & $\begin{array}{r}10 \\
10 \\
12 \\
3\end{array}$ & $\begin{array}{l}2 \\
3 \\
1 \\
0\end{array}$ & $\begin{array}{l}33.50 \\
32.00 \\
27.25 \\
17.25\end{array}$ \\
\hline Papilla & & & & & & \\
\hline (2) & $\begin{array}{l}23 \\
12\end{array}$ & $\begin{array}{l}17 \\
18\end{array}$ & $\begin{array}{l}55 \\
27\end{array}$ & $\begin{array}{r}6 \\
35\end{array}$ & $<1$ & $\begin{array}{l}36.25 \\
53.25\end{array}$ \\
\hline
\end{tabular}

\section{Discussion}

PfLeiderer and Wachsmuth (2) have grouped the tissues from human adults according to their LDHisoenzyme patterns. In heart, exythrocytes, brain and kidney LDH-1 and LDH-2 are predominant, while in liver, skeletal muscle and malignant tissues LDH-4 and LDH- 5 are the strongest fractions. Most other organs show isoenzyme patterns with peaks in LDH-3 or LDH-4.

For the kidney such a classification can no longer be maintained. The present investigation reveales that it is not justified to talk about the LDH-isoenzyme pattern of the kidney, but rather of $\mathrm{LDH}$-isoenzyme patterns characteristic of glomeruli, convoluted tubules etc.

$\mathrm{LDH}$ is an enzyme of the glycolytic pathway. KapLan's group has advanced the idea that prevalency of LDH-1 is characteristic for tissues with aerobic metabolism, such as heart, and prevalency of LDH- 5 for tissues which function anaerobically, such as skeletal muscle (19). This theory is based on the observations that purified LDH-1 is inhibited by relatively low concentrations of pyruvate and purified LDH-5 much higher concentrations, and it was concluded that in tissues with oxidative metabolism the presence of LDH-1 would permit oxidation of pyruvate via the citrate cycle, while the presence of LDH-5 in tissues with anaerobic metabolism would make possible the accumulation of lactate $(19,22)$. 
Moreover in tissue cultures (20) and in developing chicken embryos (24) more M-subunits are being synthesized in an hypoxic environment, suggesting the dependence of LDH-isoenzyme synthetics on oxygen supply. Vesell (23) has on experimental grounds questioned the general validity of KAPLAN's theory. The difference of inhibition by pyruvate and lactate between LDH-1 and $\mathrm{LDH}-5$ disappears almost completely under more physiological conditions.

Metabolism and LDH-isoenzyme pattern of the erythrocyte has been held against KapLAN's theory. The mature erythrocyte generates energy mainly through glycolysis, and only very little through oxidation of glucose via the shunt pathway. Yet LDH-1 and LDH-2 are the major fractions of the $\mathrm{LDH}$-isoenzymes. In the early stages of development and maturation the red cell contains a nucleus, mitochondria and ribosomes, and is equipped for oxidative metabolism. Starkweather et al. (18) found LDH-5 to be the major component of the isoenzymes in immature erythrocytes, and attributed the loss of LDH-4 and LDH-5 simply to their known instability. Pfleidderer and Wachsmuth (2), who first pointed to the discrepancy between $\mathrm{LDH}$-isoenzyme pattern and type of metabolism, felt that the mature erythrocyte in which protein (enzyme) synthesis has ceased, can no longer be regarded as a "normal" cell.

But there is certainly another aspect which has not been stressed in these discussions. It appears that one of the main functions. of glycolysis in the mature erythrocyte is to provide $\mathrm{NADH}_{2}$ for the reduction of methemoglobin. In hereditary methemoglobinemia the enzyme system to reduce methemoglobin is lacking and $\mathrm{NADH}_{2}$ is mainly used in the $\mathrm{LDH}$ reaction. The lactate/pyruvate quotient rises accordingly (25). The erythrocyte then is not only an exception to KAPLAN's theory but constitutes an example that factors other than the type of metabolism, aerobic or anaerobic, may determine the LDHisoenzyme pattern of a cell. The same probably applies to other tissues. As we shall see only the $\mathrm{LDH}$-isoenzyme patterns of the rat kidney are consistent with the anaerobic metabolism of the medulla, while in man, dog and rabbit they are not.

The precise role of the hybrids, LDH-2, LDH-3 and LDH-4 is still not fully understood. CAHN et al. (19) suggest that hybrids are not important as distinctive enzymes, since the individual subunits function independently of each other within an enzyme molecule, and what may be important to the cell are the relative amounts of $\mathrm{M}$-(muscle)-subunits and $\mathrm{H}$-(heart)-subunits. DAwson et al. (20) have used the catalytic differences of LDH-1 and LDH-5 with derivatives of NAD to determine the proportions of $\mathrm{H}$ - and $\mathrm{M}$-subunits in tissue extracts. KeMP (21) has calculated the percent M-subunits in kidney from LDH-isoenzyme patterns. A low percentage of M-subunits is synonymous with a LDHisoenzyme pattern in which LDH-1 and LDH-2 prevail, while a high percentage of $\mathrm{M}$-subunits indicates the presence of predominantly the slow moving fractions. This yields a single number to express isoenzyme patterns. Percent M-subunits are included in our tables and serve in figure 2 to describe species differences.

In the kidney of experimental animals oxidative metabolism prevails in the cortex and anaerobic metabolism in the medulla. The main energy source are fatty acids in the cortex and glucose in the medulla, as found in the rabbit kidney (26). A high rate of anaerobic glycolysis in the renal medulla was first described by GYörGY et al. (27) and confirmed by several authors $(28,29)$.

DAvirs et al. (30) calculated that the energy yield from glycolysis appears insufficient for medullary work. A respiratory capacity of the medulla, almost as high as that of cortex, and a considerable glycolytic capacity of the cortex was demonstrated by DAvIs (29) with the WARBURG technique. He further calculated that the critical $\mathrm{pO}_{2}$, which would allow respiration to proceed in vivo, is far less than the observed $\mathrm{pO}_{2}$ in the medulla and even in the papilla. KRAMER et al. (31) derived from measurements of the blood flow in the dog kidney in situ, that the medullary blood flow is approximately $5 \%$ of that of the cortex, and the $\mathrm{O}_{2}$-consumption of the medulla about $4 \%$ of that of the cortex, which in absolute amounts of $\mathrm{O}_{2}$ is consistent with glycolysis prevailing in the medulla. But they presumed from their data and other evidence in the literature (32) that oxidative metabolism could become greater with increased oxygen supply to the medulla.

Data cited for the kidney of rat, rabbit and dog are not available for the human kidney, but it is generally believed that the conditions are similar.

In the human kidney the $\mathrm{LDH}$-isoenzyme patterns of the convoluted tubules and medullary rays, with predominance of the $\mathrm{LDH}-1$ and $\mathrm{LDH}-2$, are consistent with an oxidative metabolism, but in the various zones of the medulla, including the papilla, LDH- 5 does not increase as one might expect in a tissue with anaerobic metabolism.

The M-subunits increased on the average from $14 \%$ in the convoluted tubules to $21 \%$ in OMZ, $45 \%$ in IMZ and $55 \%$ in the papilla. Within the papilla the Msubunits increased from the base to the tip. The highest single value measured in the tip of the papilla was $62 \%$ (fig. 2).

The LDH-isoenzyme patterns of the dog kidney are even less in agreement with the assumed metabolic conditions. In the convoluted tubules LDH- 5 was with $44 \%$ the strongest fraction, $\mathrm{LDH}-1$ was on the average $27 \%$ (33). Expressed in M-subunits the data were for convoluted tubules and medullary rays $60 \%$, OMZ $16 \%$, IMZ $19 \%$, papilla $39 \%$, and the very tip of the papilla $60 \%$.

In homogenates from rabbit kidney the values of the M-subunits were cortex 19\%, OMZ 16\%, IMZ 17\% and papilla $41 \%$.

Of the species investigated, only the kidney of the rat showed LDH-isoenzyme patterns conisistent with the theory of low content of M-subunits in tissue with aerobic metabolism and high content in tissues with anaerobic metabolism (14). The percentage of $M$ - 


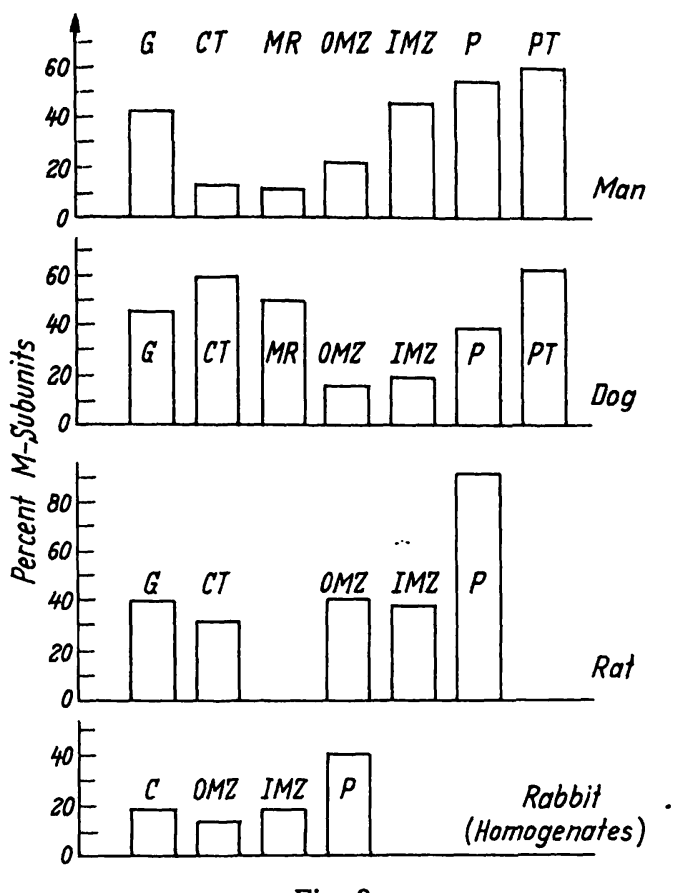

Fig. 2

LDH-isoenzymes expressed as $M$-subunits in the dissected structures of the kidney of man, dog and rat and in homogenates of the kidney of man, dog and rat and in homogenates of the kidney of the rabbit

G: glomeruli; C: cortex; CT: convoluted tubules; MR: medullary rays; OMZ: outer zone of the medulla; IMZ: inner zone of the medulla; P: papilla; PT: tip of the papilla

subunits increased from $30 \%$ in the convoluted tubules, $41 \%$ in $\mathrm{OMZ}, 37 \%$ in IMZ to $88 \%$ in the papilla (fig. 2).

From the foregoing discussion we consequently conclude, that there is no strict relation between LDH-isoenzyme patterns and the type of metabolism, respiratory or glycolytic, in the kidney. The gradual increase of $\mathrm{M}$ subunits from the outer zone of the medulla to the tip of the papilla in the kidney of man, dog and rabbit, is not as great as expected in regard to glycolysis. If this is a marked feature in conditions where glycolysis normally prevails, but respiration occurs in addition to, or can replace glycolysis to a certain extent, is not known. It also is possible that the patterns are adapted to reactions of $\operatorname{NAD}\left(\mathrm{H}_{2}\right)$ other than glycolysis and respiration.

It has been observed that the activity of LDH in serum is increased in some renal diseases, and it has been suggested that this increase is due to release of $\mathrm{LDH}$ from the kidney $(7,8,34)$. One would expect under these circumstances, the LDH-isoenzyme pattern of the serum to reflect to some extent the pattern which is characteristic for the part of the nephron in which the lesion occurs. But structures other than convoluted tubules are probably to small in mass to contribute significantly to an increase of total LDH activity and to a change in the isoenzyme pattern in serum, unless the cellular injury in these structures is extremely severe $(13,33)$.
As the activity of LDH-5 is low in the human kidney and is found mainly in the inner medulla and in the papilla, it was surprising when RiNGorr. $(7,8)$ found LDH-5 to be often more increased than the other LDH-isoenzymes in serum of patients with acute tubular necrosis and chronic pyelonephritis. An even more pronounced increase of LDH-5 in serum was found after hemodialysis in these patients. To account for this increase in serum by release of LDH from renal tissue, one must assume a change in the LDH-isoenzyme patterns of the kidney tissue itself. RINGorR reported on a few cases in which LDH-5 was indeed increased in homogenates from kidney cortex, but in our opinion this was not enough to justify the statement that the increase in serum was due to release from the kidney.

JAHNECKE et al. (34) believe that LDH is released from the kidney during acute renal failure of different causes and report that the "kidney specific" LDH-isoenzyme pattern is reflected in the serum. Their LDH-isoenzyme pattern is in disagreement with most of the data published, including the present study. Whether or not methodical differences are responsible for the discrepancies remains to be seen.

Acute renal failure is a clinical syndrome which can be caused by a number of diverse etiologic factors. Regardless of the etiology the final common pathway appears to be systemic hypotension or shock. In fact under any experimental conditions renal failure cannot be produced unless hypotension is concomitant. The major effects might be seen in the kidney, but one would certainly expect acute ischemic changes and eventually metabolic changes in other organs due to toxic effects of uremia per se (35). It would be very surprising if increased enzyme release into the blood would under such circumstances be limited to the kidney only.

The origin of enzyms in urine has recently been discussed in detail (13) and the following conclusion was reached: renal tissue must be regarded as the main source for enzymes in urine. In the healthy human kidney only enzymes with a molecular weight of less than about 70000 can be filtered in the glomeruli. As the molecular weight of $\mathrm{LDH}$ is approximately 150000 it cannot be derived from the serum. The LDH-isoenzyme pattern in normal human urine with predominantly LDH-1 is consistent with the conception that $\mathrm{LDH}$ in urine is derived mainly from the cortex.

Whether or not serum enzymes can penetrate the glomerular epithelium in renal disease is yet unknown. Moșt authors did not find any correlation between proteinuria and enzymuria, including LDH. One has to assume therefore that the larger portion of enzymes in urine of patients with kidney disease originate from tubular cells.

\section{References}

1. Wieland, Th., G. Plfeiderer, I. Haupt und W. Wörner, Biochem. Z. 332, 1 (1959). - 2. PrLeIDERER, G. und E. D. WAChsMUth, Biochem. Z. 334, 185 (1961). - 3. Vesell, E. S. und A. BeArN, J. Clin. Invest. 40, 586 (1961). - 4. WROBLEWSKI, F. und
K. F. Gregory, Ann. N. Y. Acad. Sci. 94, 912 (1961). - 5. Richterich, R., P. Schafroth und H. Aebr, Clin. chim. Acta (Amsterdam) 8, 178 (1963). - 6. Withycombe, W. A.; Ph. D. Thesis, Univ. of London 1965. Zit. J. H. Wilkinson, Isoenzymes. 
S. 44. J. B. Lippincott, Philadelphia (1966). - 7. RrNGorR, S., Thesis, Univ. of Gent, 1967. Toepassing van de Gedifferentieerde LDH Bepaling bij experimentele en klinische Nieraandoeningen. Arscia Uitgaven N. V., Brussel (1967). - 8. RrNGorR, S., in: Aktuelle Probleme der klinischen Biochemie, edited by H. Aebi, H. Mattenheimer, F. W. Schmidt. Vol. II. International Conference on enzymes in the urine. Hans Huber, Bern und Stuttgart, (1968). - 9. Wiene, R. J. und Y. van MaERcke, Ann. N. Y. Acad. Sci. 94, 898 (1961). - 10. Bonting, S. L., V. E. Pollak, R. C. MuehrCKe und R. M. Kark, Science Washington 127, 1342 (1958). - 11. Pollak, V. E. und H. Matrenheimer, Arch. Int. Med., Chicago 109, 473 (1962). - 12. MatTenmheier, H., V. E. Pollak, R. C. Muehrcke und R. M. Kark, Verh. Dtsch. Ges. inn. Med. 70, 579 (1964). - 13. Matrenhermer, H., in: Aktuelle Probleme der Klinischen Biochemie, edited by H. Aebi, H. Mattenheimer, F. W. Schmidt. Vol. I. Praktische Enzymologie. Hans Huber, Bern u. Stuttgart (1968). - 14. ThIELE, K. G. und H. MATTENHEIMER, this journal 4, 232 (1966). - 15. KENNY, M. A., $\mathrm{Ph}$. D. Thesis. The Graduate College, Univ. of Illinois at the Medical Center Chicago, 1967. Relationship of an electrophoretically separable variant to lactic dehydrogenase isoenzyme $2\left(\mathrm{H}_{3} \mathrm{M}\right)$ from human erythrocytes. - 16. KENNY, M. A. und M. E. RAFELSON, Presbyterian-St. Luke's Hospital Med. Bull. 6, 92 (1967). - 17. MatTenheimer, H., Mikromethoden für das klinisch-chemische und biochemische Laboratorium. 2. Aufl., Walter de Gruyter \& Co., Berlin (1966). - 18. Starkweather, W. H., L. Cousinkau, H. K. Schoch und C. J. Zarafonetis, Blood 26, 63 (1965). - 19. Cahn, R. D., N. O. Kaplan, L. Levins und E. Zwilling,
Science Washington 136, 962 (1962). - 20. DAwson, D. M., T. L. GoodfrIEND und N. O. KAPLAN, Science Washington 143, 929 (1964). - 21. KEMP, E., in: Aktuelle Probleme der klinischen Biochemie, edited by H. Aebi ,H. Mattenheimer, F. W. Schmidt. Vol. II. International Conference on enzymes in the urine. Hans Huber, Bern u. Stuttgart (1968). - 22. PlagemanN, P. G. W., K. F. Gregory und F. WroblewsKr, J. biol. Chemistry 235, 2288 (1960). - 23. Veseld, E. S., Science Washington 150, 1590 (1965). - 24. LINDY, S. und M. Rajasalm, Science Washington 153, 1401 (1966). - 25. WALLER, H. D., in: Erbliche Stoffwechselkrankheiten, edited by F. Linneweh, p. 74. Urban und Schwarzenberg, München-Berlin (1962). - 26. LEE, J. B., V. K. VANCE und G. F. Cahilt, Amer. J. Physiol. 203, 27 (1962). - 27. György, P., W. KELLER und T. BreHME, Biochem. Z. 200, 356 (1928). - 28. Dickens, F. und H. WeIL-Malmerbe, Biochem. J. 30, 659 (1936). - 29. Davis, R. P., in: Progress in Pyelonephritis, edited by E. H. Kass. S. 408. F. A. Davis Company, Philadelphia (1965). 30. Davies, R. E., R. W. Winters und E. L. Kean, Federat. Proc. 21, 427 (1962). - 31. Kramer, K., K. Thurau und P. Deetjen, Pflügers Arch. ges. Physiol. 270, 251 (1960). - 32. Ulirich, K. J., Erg. Physiol. 50, 433 (1959). - 33. Mattenhermer, H., in: Aktuelle Probleme der klinischen Biochemie, adited by $\mathrm{H}$. Aebi, $\mathrm{H}$. Mattenheimer, F. W. Schmidt. Vol. II. International Conference on enzymes in the urine. Hans Huber, Bern u. Stuttgart (1968). 34. Jahnecke, J., G. Löffler, M. Meisch und E. Streichen, Klin. Wschr. 45, 466 (1967). - 35. Schreiner, G. E. und J. F. MAHER, Uremia: Biochemistry, Pathogenesis, Treatment. Charles C. Thomas, Springfield, Illinois, Section III.

Prof. Dr. H. Mattenheimer Presbyterian St. Luke's Hospital 1753 W. Congress Parkway Chicago, Ill., USA 60612

\title{
Kombinierte enzymatische Methode zur Bestimmung von 3-Hydroxykynurenin und 3-Hydroxyanthranilsäure in freier und veresterter Form im Harn
}

\author{
Von H. SCHIEVELbEIN und KARIN LöSCHENKoHL
}

Aus dem Klinisch-Chemischen Institut an der Chirurgischen Universitätsklinik München (Direktor: Prof. Dr. Dr. E. Werle)

(Eingegangen am 1. Februar 1968)

3-Hydroxykynurenin wird mit Kynureninase (L-Kynurenin-Hydrolase, EC 3.7.1.3) zu 3-Hydroxyanthranilsäure umgesetzt. In einer nachfolgenden Reaktion wird diese Verbindung mit 3-Hydroxyanthranilsäureoxydase (3-Hydroxyanthranilat : $\mathrm{O}_{2}$ Oxydoreduktase, EC 1.13.1.6) zu 2-Akrolein-3-aminofumarat oxydiert. Dieses Reaktionsprodukt kann bei $360 \mathrm{~nm}$ quantitativ bestimmt und so die Konzentration der beiden Tryptophanstoffwechselprodukte im Harn errechnet werden.

3-Hydroxykynurenine is degraded by kynureninase (L-kynurenine hydrolase, EC 3.7.1.3) to 3-hydroxyanthranilic acid. In a subsequent reaction, this compound is oxidised by 3-hydroxyanthranilic acid oxidase (3-hydroxyanthranilate : $\mathrm{O}_{2}$ oxidoreductase, EC 1.13.1.6) to 2-acroleine-3-aminofumarate. This reaction product can be estimated quantitatively at $360 \mathrm{~nm}$ and thus the concentration of the two tryptophane metabolites can be calculated.

Seit dem chromatographischen Nachweis von 3Hydroxyanthranilsäure ${ }^{1}$ ) im Harn von tuberkulösen Patienten nach oraler Tryptophanbelastung durch Musajo und Mitarbeiter (1) 1952 sind zahlreiche Veröffentlichungen erschienen, in welchen das Ausscheidungsmuster von Tryptophanmetaboliten bei verschiedenen pathologischen Zuständen beschrieben wird (Literaturübersicht bis 1964 bei Musajo und BeNASSI (2)). Eine besondere Bedeutuing erlangte die Bestim-

1) Abkürzungen: 3-OH-A = 3-Hydroxyanthranilsäure. 3-OH-K= 3-Hydroxykynurenin, PLP = Pyridoxal-5'-phosphat. mung von Tryptophanmetaboliten im Harn, nachdem Boyland (3) gefunden hatte, daß Patienten mit einem Carcinom der Harnblase gegenüber Normalen eine erhöhte Ausscheidung der im Tierexperiment carcinogenen Stoffwechselprodukte 3-OH-A und 3-Hydroxykynurenin aufweisen. Für die Bestimmung der erwähnten Substanzen im Harn wurden eine Reihe von Methoden angegeben, welche infolge ihres Mangels an Spezifität oder ihrès großen Aufwandes für die Untersuchung einer größeren $\mathrm{Zahl}$ von Proben nur bedingt geeignet sind. 